\title{
Types of internal Diesel injector deposits and counteracting their formation
}

\begin{abstract}
The paper attempts to distinguish types of IDID (Internal Diesel Injector Deposits) with regard to the mechanism of formation, factors facilitating their formation and the method of identification. Investigations into their formation mechanism have been discussed in the paper. The results of the investigations into the chemical nature and probable source of these deposits have also been discussed. It has been pointed out that modern common rail fuel injection systems might be less tolerant to deposits due to tighter fitting tolerances, lower mass of parts and sophisticated injection strategies. Various approaches to IDID formation counteracting have also been discussed.
\end{abstract}

Key words: injector internal deposits, diesel engines, fuel injection systems

\section{Przegląd typów osadów wewnętrznych we wtryskiwaczach silników z zapłonem samoczynnym oraz przeciwdzialanie ich powstawaniu}

\begin{abstract}
$W$ artykule przedstawiono próbę podziału wewnętrznych osadów wtryskiwaczy paliwa na typy, biorac pod uwage mechanizmy ich tworzenia, czynniki sprzyjajace ich powstawaniu oraz sposoby identyfikacji. Zaprezentowano badania dotyczace mechanizmów tworzenia takich osadów. Opisano także wyniki badań natury chemicznej i prawdopodobnych źródeł powstawania osadów. Zwrócono uwagę, że nowoczesne systemy wtrysku paliwa typu common rail są mniej odporne na oddziaływanie osadów ze względu na mniejsze tolerancje wykonawcze, mniejszą masę elementów roboczych i zaawansowane strategie wtrysku paliwa. Opisano też różne sposoby przeciwdziałania tworzeniu się osadów typu IDID.

Słowa kluczowe: osady wewnętrzne we wtryskiwaczach paliwa, silniki z zapłonem samoczynnym, układy wtrysku paliwa
\end{abstract}

\section{Introduction}

The increasingly stringent environmental legislation, (incl. limitation in the exhaust emissions from piston combustion engines) manifests itself as the EURO emission standards. The EURO VI emission standard came into force as of 1 September 2014 in Europe for newly homologated vehicles and as of 1 September 2015 will become applicable for newly registered vehicles. The European Union is introducing further limits on the $\mathrm{CO}_{2}$ emissions from passenger vehicles, light duty trucks, buses and heavyduty trucks. These limits are a serious challenge for the manufacturers of piston combustion engines in terms of adaptation to the above-mentioned legislation and fulfillment of the growing requirements and expectations of the end users. This objective is realized by reducing the fuel consumption while still maintaining the engine operating parameters and its performance (downsizing) as well as by maximum qualitative and quantitive optimization of the mixture formation. The fundamental assumption of these actions is to boost the engine efficiency and reduce the exhaust emissions and noise.

The popularization of direct injected diesel engines (compression ignition) and a constant advancement of the HPCR system (High Pressure Common Rail) continuing since 1997 have played an important role in the achievement of the said objectives. Further optimization of the mixture formation will be decisive of the increase in the engine efficiency, reduced fuel consumption (emission of $\mathrm{CO}_{2}$ ) and exhaust emissions. As is forecasted, it will be conditioned by and directly related to further advancement of precise high-pressure injection systems [1-3].

\section{Wstęp}

Systematycznie zaostrzane przepisy dotyczące ochrony środowiska naturalnego, w tym powietrza, a zatem i ograniczenia emisji składników szkodliwych w gazach spalinowych z tłokowych silników spalinowych, znajdują odzwierciedlenie w kolejnych wydaniach Europejskich Norm Emisji Spalin (EURO). Norma EURO VI zaczęła obowiązywać w Europie od 1 września 2014 r. w zakresie homologacji, a od 1 września 2015 r. obowiązuje w zakresie rejestracji oraz sprzedaży nowych typów pojazdów. Ponadto w Unii Europejskiej wprowadzane są też dalsze ograniczenia emisji $\mathrm{CO}_{2}$ z samochodów osobowych, lekkich pojazdów dostawczych i autobusów oraz samochodów ciężarowych. Ograniczenia te stawiają duże wyzwania przed producentami tłokowych silników spalinowych, mając na względzie konieczność dostosowania ich do powyższych przepisów, a zarazem do nieustannie rosnących wymagań i oczekiwań użytkowników. Realizacja tych celów następuje przez dążenie do ograniczenia wielkości zużycia paliwa przez silniki, przy zachowaniu ich osiągów i parametrów użytkowych (downsizing), oraz maksymalną poprawę w zakresie przygotowania ilości i jakości mieszanki spalanej w cylindrach silników. Zasadniczym założeniem takich działań jest podwyższenie sprawności silników oraz obniżenie emisji składników szkodliwych, a także hałasu.

Rozpowszechnienie silników ZS (z zapłonem samoczynnym) z wtryskiem bezpośrednim i postępujący od $1997 \mathrm{r}$. rozwój układów wysokociśnieniowego wtrysku paliwa typu HPCR (High Pressure Common Rail) odegrały znaczącą rolę $\mathrm{w}$ dotychczasowym osiąganiu powyższych celów. Dalsze optymalizacje procesów tworzenia mieszanki palnej 


\section{Trends in the development of high-pressure injection systems - threats}

The application of HPCR systems enabled a separation of the process of injection from the process of fuel pumping, made the fuel injection pressure independent of the engine speed and enabled a precise fuel division into subdoses with their accurate control, which created new possibilities of control of the fuel dosage quality that were thus far unobtainable. High fuel injection pressures lead to its better atomization in the combustion chambers and positively influence the quality of the mixture and the possibility of dividing the fuel dose into multiple subdoses within a single cycle allow a flexible adaptation of the fuel quantity to the course of the combustion process reducing the noise and optimizing the combustion pressures. The application of many variants of multiple injection allows the control of the course of combustion enabling a reduction of the exhaust emissions. As a consequence, further advancement of fuel HPCR injection systems will aim at increasing the maximum fuel pressure and better atomization following the use of a greater number of injection holes of smaller diameters [1-3]. Precise control of the fuel rate injected in a single injection will become increasingly important by dividing it into a maximum number of individual subdoses with possibly shortest dwell times or by a smooth control of the injector needle movement in each individual injection. A smooth variation of the fuel pressure is also considered during the course of the injection. The application of such complex fuel injection strategies already on the level of a single injection will require injectors of very short reaction time (maximum increase in the pulse frequency) or their smooth control (smooth control of the pulses). This entails the need to manufacture increasingly smaller and lighter components and injector actuators. Figure 1 presents the changes in the size of this elementary component throughout decades (on the example of a needle from a high pressure pump nozzle manufactured in 1990s of the last century and a modern electromagnetic high pressure HPCR injector.

a)

)

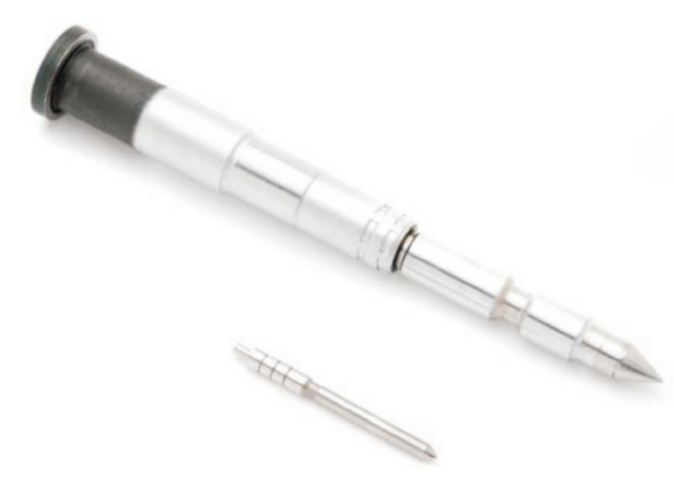

Fig. 1. Comparison of the injector needles from a high pressure injection system manufacture in the 1990 s of the last century (a) and a modern one (b) [4]

Rys. 1. Porównanie wielkości iglicy wtryskiwaczy układu wysokociśnieniowego wtrysku paliwa z lat 90. ubiegłego wieku (a) i obecnie stosowanego (b) [4] i spalania będą miały decydujące znaczenie dla zwiększenia sprawności silników, skutkującej zmniejszeniem zużycia paliwa, a więc i emisji $\mathrm{CO}_{2}$, a także ograniczeniem wielkości emisji składników szkodliwych do atmosfery. Jak się przewiduje, będzie to uwarunkowane i bezpośrednio związane z dalszym rozwojem precyzyjnie działających układów wysokociśnieniowego wtrysku paliwa [1-3].

\section{Kierunki rozwoju układów wysoko- ciśnieniowego wtrysku paliwa - zagrożenia}

Stosowanie układów HPCR pozwoliło na rozdzielenie procesu wtrysku paliwa od tłoczenia paliwa, uniezależniło ciśnienie wtrysku paliwa od prędkości obrotowej silnika i umożliwiło precyzyjne dzielenie dawki paliwa na części przy ich dokładnym sterowaniu w czasie, co stworzyło nowe, dotychczas nieosiągalne, możliwości w zakresie podnoszenia jakości procesów dawkowania paliwa. Wysokie ciśnienia wtrysku paliwa powodują jego lepsze rozpylenie w komorach spalania i korzystnie wpływają na jakość tworzenia mieszanki palnej, a możliwość podziału dawki wtryskiwanego paliwa na kilka części w czasie jednego cyklu spalania pozwala w sposób elastyczny dostosowywać ilość doprowadzanego paliwa do przebiegu procesu spalania, obniżając hałas pracy silnika i korzystnie kształtując przebiegi wzrostu ciśnienia spalania. Zastosowanie różnych wariantów wtrysku wielokrotnego pozwala na kontrolowanie przebiegu procesów spalania, umożliwiając ograniczanie emisji. W konsekwencji dalszy rozwój układów wtrysku paliwa typu HPCR będzie zmierzał nie tylko do dalszego zwiększania ciśnienia wtrysku paliwa i jego lepszego rozdrobnienia dzięki stosowaniu większej ilości i mniejszej średnicy otworków wtrysku paliwa [1-3]. Coraz większe znaczenie będzie miało również precyzyjne sterowanie wielkością natężenia paliwa wtryskiwanego w czasie pojedynczej dawki przez jej podział na jak największą ilość zróżnicowanej wielkości części z maksymalnym skróceniem czasów pomiędzy ich wtryskiwaniem lub przez płynne sterowanie ruchem iglicy wtryskiwacza podczas każdego, pojedynczego wtrysku paliwa. Brana jest też pod uwagę płynna zmiana wielkości ciśnienia paliwa podczas przebiegu wtryskiwania pojedynczej dawki. Zastosowanie tak złożonych strategii sterowania wtryskiem paliwa już w zakresie kształtowania pojedynczej dawki będzie wymagało zastosowania wtryskiwaczy o bardzo krótkim czasie przesterowania (maksymalne zwiększenie częstotliwości impulsów sterujących) lub ich płynnego sterowania (płynne kształtowanie przebiegu impulsów sterujących). Wiąże się to między innymi z koniecznością wykonywania coraz mniejszych i lżejszych elementów sterujących i roboczych wtryskiwaczy. Na rysunku 1 przedstawiono, na przykładzie iglicy pochodzącej z pompowtryskiwacza układu wysokociśnieniowego wtrysku paliwa z lat 90. XX w. i iglicy z nowoczesnego, obecnie stosowanego elektromagnetycznego wtryskiwacza układu typu HPCR, jak zmieniła się wielkość tego podstawowego elementu roboczego wtryskiwacza na przestrzeni kilkunastu lat.

Tak duże zmiany w wielkości, masie, ale także w konstrukcji układów wysokociśnieniowego wtrysku paliwa 
The changes in the size, mass and design of high pressure fuel systems are big. Back in the 1990s of the last century a force needed to realize a single injection by a pump nozzle was $17600 \mathrm{~N}$, while in modern HPCR injectors the force needed to realize a multiple injection is $40 \mathrm{~N}[1,5]$.

The necessity to carry out increasingly accurate multiple injections by dividing doses into a greater number of smaller subdoses with more accurate injection onsets and durations led to a popularization of piezoelectric injectors (enabling a very short reaction - 3-4-times shorter compared to electromagnetic injectors). In this type of injectors, the needle is directly coupled with the piezoelectric component composed of almost a hundred layers of crystals that expand and contract with the voltage impulses sent by the electronic engine control. The crystals change their length by a total of $0.4 \mathrm{~mm}$, which is sufficient to precisely open and close the injector. This allows a better dosage accuracy and stability and the possibility of dividing doses into more than 7 subdoses, thus, providing an optimal course of combustion. Thus far, multiple fuel dose division was difficult due to the inertia of the electromagnetic valves and the actuators used in the injectors. As mentioned before, the most advantageous fuel dose division is obtained with a pre-injection composed of a few very small fuel portions, after which the main injection with post-injections occurs. If the pre-injections do not exceed the volume of $1 \mathrm{~mm}^{3}$, the pressure at the moment of self-ignition increases smoothly, which makes the engine less noisy. With the post injections we can efficiently adjust the composition of the exhaust gas. The fuel injected into the cylinder at the end of combustion leads to the afterburning of the soot particles and in exhaust systems fitted with DPF increases the exhaust temperature, which regenerates the filter. Rapid evolution of the design of high-pressure injection systems led to their greater complexity, miniaturization and better workmanship of their components. For example, the diameters of the fuel injector holes have a tolerance of 0.2 to $0.1 \mathrm{~mm}$ while the maximum admissible deviations from these diameters cannot exceed several thousandths of a millimeter. The play between the nozzle casing and the guiding needle, amounts to approx. $1 \mu \mathrm{m}$, the play of the valve plunger controlling the fuel flow in the DELPHI injectors amounts to $0.5 \mu \mathrm{m}$, and the operating lift of the control plunger cap is below $30 \mu \mathrm{m}[1,2,6]-$ Fig. 2 .

Such high precision requirements for the injectors are not only the attempt to obtain the shortest time of their reaction to ensure the exact moment of their opening and duration of the injection to the combustion chamber but also to prevent any possible leakage bearing in mind that the operating fuel injection pressure may reach 250-300 MPa.

Along the changes in the design and technology of the subsequent generations of high pressure of injection systems came significant changes in the technology of production of fuels that are also used for the lubrication of the injection systems, including HPCR. The popularization of low sulfur diesel fuels and fuel additives gave way to fuels containing acid components. For example, to a different extent, unsaturated fatty acids are commonly used as lubricant sprawiły, między innymi, że w latach 90. ubiegłego wieku siła potrzebna do uruchomienia pompowtryskiwacza i wykonania pojedynczego wtrysku paliwa wynosiła $17600 \mathrm{~N}$, podczas gdy w obecnie stosowanych układach wtryskowych typu HPCR siła niezbędna do wykonania pojedynczego, wielokrotnego wtrysku paliwa wynosi $40 \mathrm{~N}[1,5]$.

Konieczność coraz większej dokładności realizacji procesów dozowania paliwa przez podział wtryskiwanej dawki na coraz większą ilość, coraz mniejszych części, przy coraz bardziej precyzyjnej kontroli początku i czasu wtrysku doprowadziła już do rozpowszechnienia stosowania wtryskiwaczy piezoelektrycznych, zapewniających bardzo krótki czas przesterowania (3-4-krotnie krótszy względem wtryskiwaczy elektromagnetycznych). We wtryskiwaczach tego typu iglica zaworu dozującego sprzężona jest bezpośrednio z elementem piezoelektrycznym, złożonym z ponad stu warstw kryształów, który rozszerzając się i kurcząc pod wpływem impulsów napięciowych wysyłanych przez elektroniczny sterownik silnika wydłuża (lub kurczy) się łącznie o cztery setne milimetra, co wystarcza do precyzyjnego otwierania i zamykania zaworu wtryskiwacza. Pozwala to na większą dokładność i stabilność dozowania oraz możliwość podziału dawki na ponad siedem wtrysków, a w rezultacie optymalny przebieg procesu spalania. Dotychczas było to utrudnione zbyt dużą bezwładnością zaworów elektromagnetycznych i wykonawczych elementów roboczych stosowanych we wtryskiwaczach. Jak już stwierdzono, najkorzystniejszy podział dawki paliwa uzyskuje się przy wtrysku wstępnym złożonym z kilku bardzo małych porcji paliwa, po których następuje wtrysk główny oraz wtryski dodatkowe. Jeśli wtryski wstępne nie przekraczają objętości $1 \mathrm{~mm}^{3}$, ciśnienie w momencie pojawienia się samozapłonu wzrasta w komorze spalania bardzo łagodnie i dzięki temu silnik jest mniej hałaśliwy. Za pomocą wtrysków dodatkowych można z kolei korzystnie korygować skład emitowanych spalin. Paliwo wtryśnięte do cylindra pod koniec procesu spalania powoduje bowiem dopalanie cząsteczek sadzy, a w układach wydechowych z filtrem cząstek stałych DPF podnosi temperaturę splin, co wspomaga procesy regeneracji DPF. Jak z tego wynika, szybka ewolucja konstrukcji współczesnych układów wysokociśnieniowego wtrysku paliwa sprawiła, że są one coraz bardziej skomplikowane, ich elementy składowe są coraz mniejsze, a zarazem coraz dokładniej wykonane. Dla przykładu, średnice otworków wtrysku paliwa zawierają się w przedziale od 0,2 do 0,1 $\mathrm{mm}$, a dopuszczalne, wykonawcze odchyłki średnic tych otworków nie mogą przekraczać kilku tysięcznych milimetra. Luz pomiędzy obudową rozpylacza i poruszającą się w nim walcową, prowadzącą częścią iglicy wynosi około $1 \mu \mathrm{m}$, luz nurnika zaworka sterującego przepływem paliwa we wtryskiwaczach firmy DELPHI to $0,5 \mu \mathrm{m}$, a roboczy wznios grzybka nurnika sterującego wynosi poniżej $30 \mu \mathrm{m}$ $[1,2,6]-$ rys. 2 .

Tak wysokie wymagania wykonawcze stawiane wtryskiwaczom są związane nie tylko z dążeniem do uzyskiwania jak najkrótszego czasu ich przesterowania, tak aby zagwarantować odpowiednią chwilę otwierania i odpowiedni 


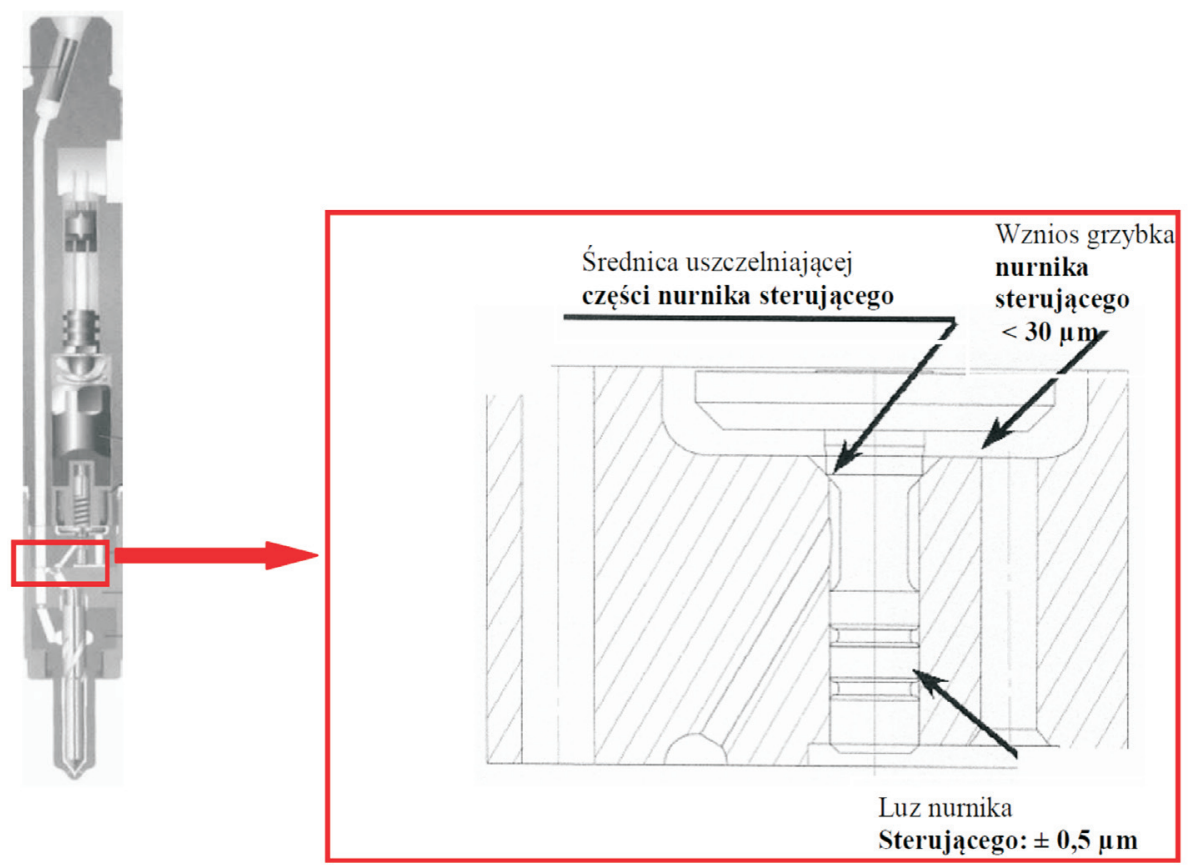

Fig. 2. Operation of an electromagnetic valve controlling the fuel flow in the Delphi injectors Rys. 2. Działanie zaworu elektromagnetycznego sterujacego przepływem paliwa we wtryskiwaczu firmy Delphi

additives. These acids easily react with metallic ions of the fuel contaminants forming carboxylic salts, that, similarly to low molecular mass polar compounds, much worse dissolve in low sulfur diesel fuels of low content of aromatic hydrocarbons compared to old high sulfur content fuels $[1-3,7,8]$. A growing share of FAME (characterized by low stability) in the diesel fuels accelerates the process of fuel oxidation and degradation. FAME are a source of weak acids and lead to an increase in the fuel contamination (sodium compounds) - a component of typical catalysts used in the reaction of transestrification [1, 3, 6-9]. Hence, due to their low stability, the resistance to oxidation is one of the most important properties of diesel fuels containing FAME. The results of oxidation are products compromising proper engine operation, high pressure injection systems in particular, which is why, according to the Polish Standard PN-EN 590, the induction period marked with the EN 15751 method for diesel fuels should be longer than $20 \mathrm{~h}$. Besides, corrosion inhibitors $\left(\mathrm{NaNO}_{2}\right)$ sometimes used in diesel fuels are an additional source of fuel contamination with sodium.

\section{Mechanisms and factors facilitating internal deposit formation in HPCR injection systems}

The above-described trends in the development of HPCR systems resulted in changes in the physicochemical factors that have influence on the fuel in modern diesel HSDI (High Speed Direct Injection) engines. The most important are very high injection pressures reaching $300 \mathrm{MPa}$. During the injection of the fuel compressed to the pressure of $250 \mathrm{MPa}$ or during its release (leakage between injector and the components) the processes of shearing of the conditioning additives occur along with an abrupt increase in the temperature. Then, the conversion of the pressure energy (through dissipation of czas trwania wtrysku paliwa do komór spalania, ale także z koniecznością zabezpieczenia przed wszelkimi przeciekami, mając na uwadze, że obecnie maksymalne ciśnienie wtrysku paliwa osiąga 250-300 MPa.

Równocześnie ze zmianami konstrukcyjno-technologicznymi kolejnych generacji układów wysokociśnieniowego wtrysku paliwa następowały istotne zmiany w technologii produkowanych paliw, wykorzystywanych też do smarowania układów wtrysku paliwa, w tym układów HPCR. Rozpowszechnienie niskosiarkowych olejów napędowych oraz stosowanych do ich uszlachetniania pakietów dodatków sprawiło, że zwierają one rozmaite komponenty kwasowe. Przykładowo, w różnym stopniu nienasycone kwasy tłuszczowe są powszechnie używane jako dodatki smarnościowe. Kwasy takie łatwo reagują z jonami metali stanowiącymi zanieczyszczenia paliwa, tworząc sole karboksylowe, które podobnie jak polarne związki o małej masie cząsteczkowej znacznie słabiej rozpuszczają się w niskosiarkowych olejach napędowych, o małej zawartości węglowodorów aromatycznych aniżeli w dawniej stosowanych wysokosiarkowych $[1-3,7,8]$. Coraz większy udział FAME (charakteryzujących się małą stabilnością) w olejach napędowych wpływa na przyspieszenie procesów utleniania i degradacji paliwa. FAME stanowią źródło słabych kwasów oraz powodują wzrost zanieczyszczeń w paliwie (związki sodu), będących składnikiem typowych katalizatorów stosowanych w reakcjach transestryfikacji [1, 3, 6-9]. Zatem odporność na utlenianie jest jedną z najważniejszych właściwości olejów napędowych zawierających FAME ze względu na ich małą stabilność. Wynikiem utleniania są produkty zagrażające poprawnemu funkcjonowaniu silnika, a zwłaszcza układów wtrysku paliwa typu HPCR, w związku z czym zgodnie z normą PN-EN 590 okres indukcyjny oznaczony metodą EN 15751 dla olejów napędowych powinien przekraczać 20 h. Ponadto stosowane niekiedy w olejach napędowych inhibitory korozji w postaci azotynów sodowych $\left(\mathrm{NaNO}_{2}\right)$ stanowią dodatkowe źródło zanieczyszczania paliwa sodem.

\section{Mechanizmy i czynniki sprzyjające powstawaniu osadów wewnętrznych w ukladach wtrysku paliwa typu HPCR}

Wyżej opisane kierunki rozwoju układów wysokociśnieniowego wtrysku paliwa spowodowały znaczne zmiany czynników fizykochemicznych, które oddziałują na paliwo w układzie wtryskowym nowoczesnego silnika ZS typu 
kinetic energy) into thermal energy leads to an increase in the temperature exceeding $100{ }^{\circ} \mathrm{C}$ for the output pressure of 200 $\operatorname{MPa}[9,10]$. As a consequence, when the initial temperature is $50^{\circ} \mathrm{C}$ it increases to over $150^{\circ} \mathrm{C}$. Given the temperature to which the injection nozzle placed directly in the combustion chamber heats up, the collective instantaneous temperature acting on the compressed fuel may even exceed $300^{\circ} \mathrm{C}$. This is the highest temperature that acts on the fuel in the entire HPCR fuel system. The performed investigations revealed that an increase in the fuel pressure in the injector from 200 $\mathrm{MPa}$ to $250 \mathrm{MPa}$ results in a proportional increase in the temperature by $25 \%$ [10]. As a consequence, such high fuel injection pressures significantly facilitate fuel atomization and charge homogenization inside the cylinders but at the same time lead to an increase in the fuel temperature that accelerates the processes of its oxidation and degradation (particularly if the stability of the fuel is low - FAME content). An additionally important factor accelerating these processes is multiple application of high pressures and temperatures to the fuel in the injection system due to its recirculation. In majority of currently applied HPCR systems the fuel is fed with a sizeable surplus to the injectors, which makes part of it (the part not fed to the cylinders) go to the overflow lines and then back to the tank. The fuel heated in the high-pressure pump and then in the injectors, increases the temperature of the entire content of the tank to over $60{ }^{\circ} \mathrm{C}$. This intensifies the processes of systematic and accelerated degradation of fuel and facilitates the formation of internal deposits (IDID) on the injector components.

The mechanism of IDID deposit formation is different from that of external deposits on the injection nozzles, because internal deposits are not exposed to exhaust gas generated during combustion and surface evaporation of fuel. IDID are formed as a result of precipitation of particles of insoluble compounds and their subsequent adhesion to metal parts of the injector components, particularly in spots of high pressures and temperatures and spots where the fuel transfers from high to atmospheric pressure (injection, leakage). IDID are formed in all types and designs of modern HPCR injectors - Fig. 3.

Currently manufactured low sulfur diesel fuels of low content of aromatic hydrocarbons are characterized by much lower solubility of carboxylic salts and polar compounds of low molecular mass and require lubrication additives and sometimes even corrosion inhibitors. Besides, the growing share content of FAME in diesel fuels increases the amount of sodium in the fuel because this metal is a component of typical catalysts used in the process of transestrification. The ions of sodium captured by the fatty acids being by-products of FAME used as lubrication additives, generate deposits in the form of sodium soaps that subsequently precipitate as IDID due to poor solubility in the fuels [1-3, 5, 6, 8-11]. FAME may additionally facilitate the formation of IDID due to the contaminants formed in the process of FAME production and those formed by auto-catalytic divisions of fatty esters with the participation of metal ions. Polar acid molecules bond sodium and other metals forming carboxylic
HSDI (High Speed Direct Injection). Do najistotniejszych z nich należą bardzo wysokie ciśnienia wtrysku paliwa sięgające $300 \mathrm{MPa}$. Podczas wtryskiwania, przez otworki rozpylacza, sprężonego do $250 \mathrm{MPa}$ paliwa lub jego uwalniania (przeciekania) na skutek przedostawania się przez nieszczelności pomiędzy wewnętrznymi, roboczymi elementami wtryskiwacza, występują procesy ścinania dodatków uszlachetniających paliwo oraz gwałtowny wzrost jego temperatury. Wtedy zmiana energii ciśnienia, poprzez rozproszenie energii kinetycznej w energię cieplną, powoduje wzrost jego temperatury przekraczający $100{ }^{\circ} \mathrm{C}$ dla ciśnienia wyjściowego $200 \mathrm{MPa}[9,10]$. W konsekwencji, gdy temperatura początkowa paliwa wynosi $50{ }^{\circ} \mathrm{C}$, wzrasta ona do ponad $150^{\circ} \mathrm{C}$. Jednak, biorąc pod uwagę temperaturę, do której nagrzewa się końcówka wtryskiwacza umieszczona bezpośrednio w komorze spalania silnika, sumaryczna, chwilowa temperatura oddziałująca na sprężone paliwo $\mathrm{w}$ końcówce rozpylacza może przekraczać nawet $300{ }^{\circ} \mathrm{C}$. Jest to najwyższa temperatura jaka oddziałuje na paliwo w całym układzie wtrysku paliwa typu HPCR. Przeprowadzone badania pozwoliły ustalić, że wzrost ciśnienia paliwa we wtryskiwaczu od $200 \mathrm{MPa}$ do $250 \mathrm{MPa}$ powoduje proporcjonalny wzrost jego temperatury o $25 \%$ [10]. W konsekwencji tak wysokie ciśnienia wtrysku paliwa w znaczny sposób ułatwiają rozdrobnienie paliwa i ujednorodnienie ładunku mieszanki palnej w cylindrach silnika, ale równocześnie powodują znaczny wzrost temperatury paliwa, który przyspiesza procesy jego utleniania i degradacji (zwłaszcza gdy stabilność paliwa jest niska, np. w przypadku zawartych w nim FAME). Dodatkowo ważnym czynnikiem przyspieszającym te procesy jest wielokrotne poddawanie paliwa w układzie wtryskowym wysokim ciśnieniom i temperaturom na skutek jego recyrkulacji. W większości obecnie stosowanych układów HPCR paliwo jest podawane z dużym (kilkakrotnym) nadmiarem do wtryskiwaczy paliwa, co sprawia, że ta jego część, która nie została doprowadzona do komór spalania silnika trafia do przewodów przelewowych, a następnie ponownie do zbiornika paliwa. Nagrzane w pompie wysokiego ciśnienia, a następnie we wtryskiwaczach paliwo, spływając do zbiornika paliwa powoduje podwyższenie temperatury znajdującej się w nim dużej ilości paliwa często do ponad $60{ }^{\circ} \mathrm{C}$. Pogłębia to procesy systematycznej, przyspieszonej degradacji paliwa i sprzyja powstawaniu osadów wewnętrznych (IDID) na elementach wtryskiwaczy.

Mechanizm tworzenia osadów typu IDID jest inny od tego, który powoduje powstawanie osadów zewnętrznych na końcówkach rozpylaczy, ponieważ osady wewnętrzne nie są narażone na oddziaływanie gazów spalinowych powstających podczas spalania paliwa w komorach silnika, ani na powierzchniowe odparowywanie paliwa. IDID powstają na skutek wytrącania się z paliwa cząstek nierozpuszczalnych związków, a następnie ich przywieranie do metalowych powierzchni elementów wtryskiwaczy, zwłaszcza w miejscach poddawanych wysokim ciśnieniom i temperaturom oraz $\mathrm{w}$ tych, gdzie paliwo przechodzi od wysokiego ciśnienia do atmosferycznego (wtrysk, przecieki). IDID powstają we wszystkich typach i rozwiązaniach konstrukcyjnych aktualnie 


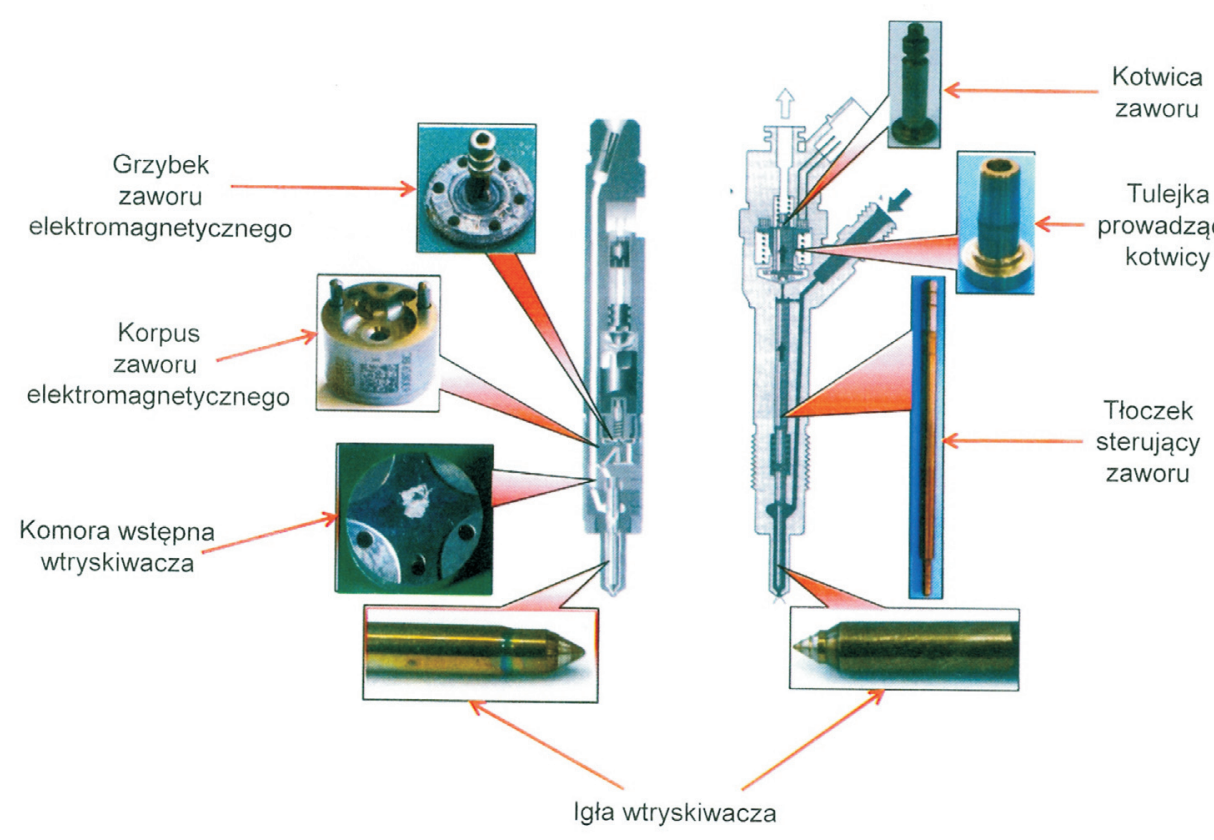

Fig. 3. Examples of typical designs of injectors in HPCR systems and their internal components exposed to IDID formation

Rys. 3. Przykłady typowych konstrukcji wtryskiwaczy układów HPCR i ich elementów wewnętrznych narażonych na tworzenie osadów IDID

salts (soaps) containing metal ions and deposits in the form of IDID on the internal surfaces of the injector components $[1,2]$. $\mathrm{NaNO}_{2}$ commonly applied as a corrosion inhibitor is made by the reaction of sodium hydroxide and the nitrogen dioxide and nitrogen monoxide. Hence, the corrosion inhibitors contain residual sodium hydroxide. The reactiveness of sodium hydroxide enables its interaction with many acidic components including those that are characteristics of the fuel aging processes, monomers and dimers of fatty acids used as lubrication additives as well as corrosion inhibitors. Carboxylic salts may form at low temperatures in the reaction of sodium (less frequently calcium, potassium) with carboxylic acids, far from the spots where deposits form (e.g. in the fuel tank or in the low pressure part of the fuel line). Then the particles insoluble in the fuel are transported with the fuel in the form of reversed micelles through the highpressure part of the fuel system. A part of them is trapped in the fuel filter, which causes its frequent clogging. Upon reaching spots of very high pressure and temperature (at spots of very abrupt fuel pressure change and its shearing) the micelles collapse forming unstable polar particles that subsequently precipitate on the internal surfaces of the injector components forming IDID [5].

Organic amides are IDID polymer deposits formed in the reactions of detergents containing polyisobuthylene succinimide (PIBSI) with the fatty or formic acids. Deposits of this type also occur in connection with carboxylic sodium salts [1-3, 5-9]. Particularly, chains of molecules of lower molecular mass are less soluble in the fuel and potentially more reactive, easily forming deposits in the areas of high temperature and pressure. Polymer deposits may also form as a result of low fuel stability, particularly if the fuel contains produkowanych wtryskiwaczy układów HPCR - rys. 3.

Produkowane obecnie niskosiarkowe oleje napędowe, o niskiej zawartości węglowodorów aromatycznych charakteryzują się znacznie mniejszą rozpuszczalnością soli karboksylowych i polarnych związków o małej masie cząsteczkowej, a zarazem wymagają stosowania dodatków smarnościowych, a w niekiedy także inhibitorów korozji. Ponadto wzrastający udział FAME w olejach napędowych wpływa na wzrost zawartości sodu w paliwie, ponieważ metal ten jest składnikiem typowych katalizatorów stosowanych w reakcjach transestryfikacji. Jony sodu przechwytywane przez kwasy tłuszczowe będące produktami ubocznymi FAME lub stosowane jako dodatki smarnościowe generują osady typu mydeł sodowych, które na skutek słabej rozpuszczalności w paliwie wytrącają się w postaci IDID [1-3, 5, 6, 8-11]. FAME mogą dodatkowo sprzyjać tworzeniu osadów typu IDID poprzez zawarte w nich zanieczyszczenia kwasowe powstałe podczas produkcji FAME oraz te uformowane przez autokatalityczny podział estrów tłuszczowych z udziałem jonów metali. Polarne cząsteczki kwasowe wiążą sód i inne metale, tworząc sole karboksylowe (mydła) zawierające jon metaliczny, osadzające się w postaci IDID na wewnętrznych powierzchniach elementów wtryskiwaczy $[1,2]$. Stosowany powszechnie jako inhibitor korozji azotyn sodowy (NaNO2) wytwarzany jest przez oddziaływanie na wodorotlenek sodu mieszaninami ditlenku azotu i tlenku azotu. W rezultacie inhibitory korozji w postaci azotynu sodowego zawierają szczątkowy wodorotlenek sodu. Reaktywność wodorotlenku sodu umożliwia jego reakcje z wieloma składnikami kwasowymi, włącznie z tymi, które są charakterystyczne dla procesów starzenia paliwa, monomerami i dimerami kwasów tłuszczowych wykorzystywanych w dodatkach smarnościowych oraz inhibitorami korozji. Sole karboksylowe mogą tworzyć się w niskich temperaturach przez reakcję sodu (znacznie rzadziej wapnia, potasu) z kwasami karboksylowymi, z dala od miejsc powstawania osadów (np. w zbiorniku paliwa lub w niskociśnieniowej części układu wtrysku paliwa). Następnie nierozpuszczalne w paliwie cząstki soli są przenoszone przez paliwo w postaci odwróconych miceli do wysokociśnieniowej części układu wtrysku paliwa. Część z nich jest przechwytywana przez filtr paliwa, który często zatykają. Po dotarciu do miejsc, gdzie występuje bardzo wysokie ciśnienie i temperatura paliwa (w miejscach gwałtownych zmian ciśnienia paliwa i jego ścinania) micele 


\begin{tabular}{|c|c|c|}
\hline 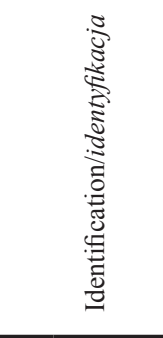 & 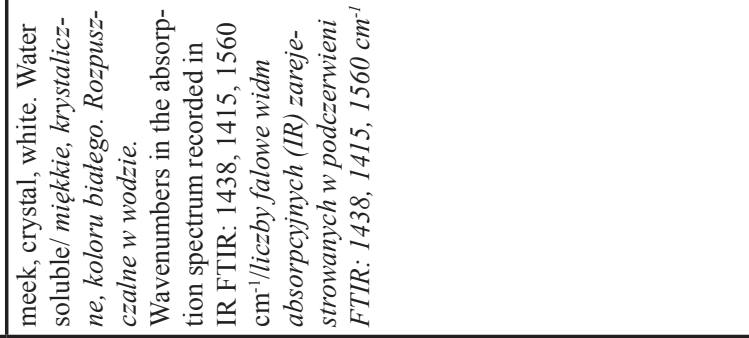 & 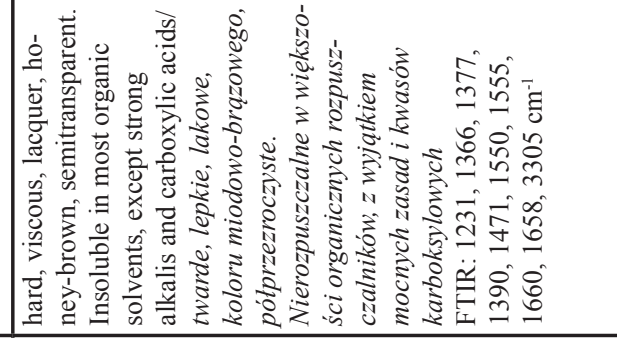 \\
\hline 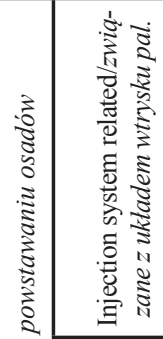 & 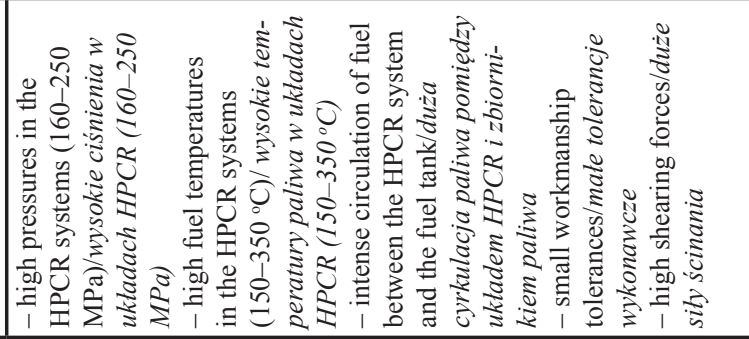 & 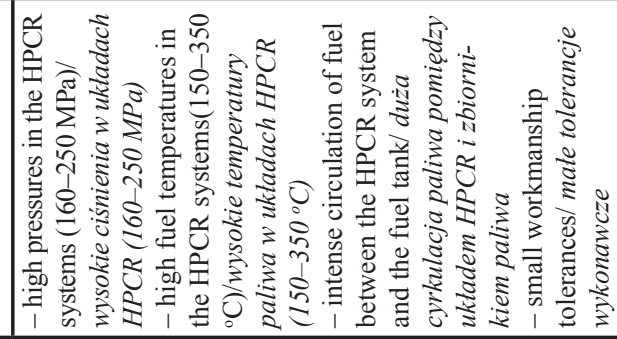 \\
\hline 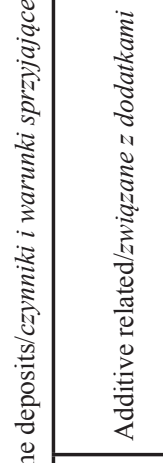 & 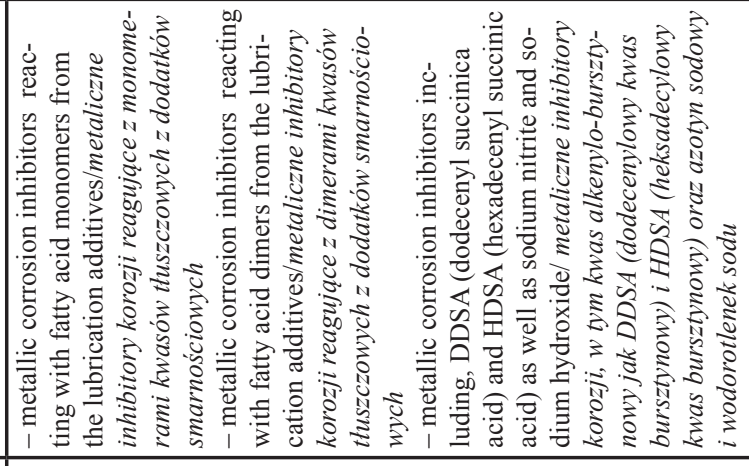 & 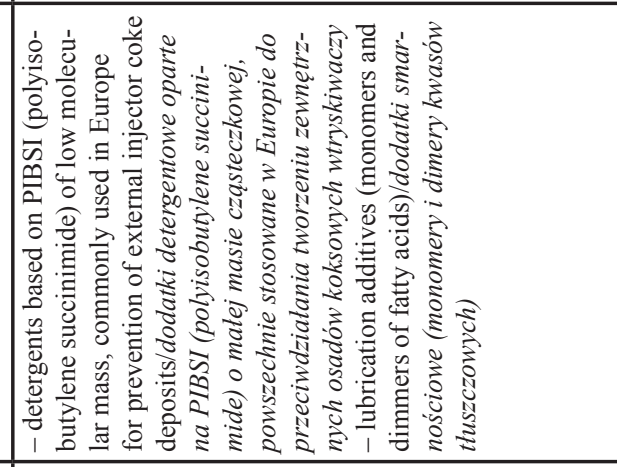 \\
\hline 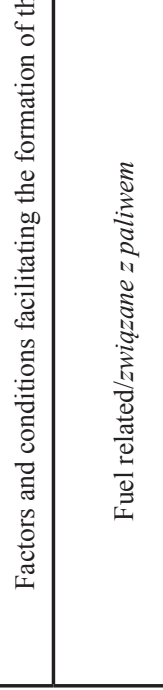 & 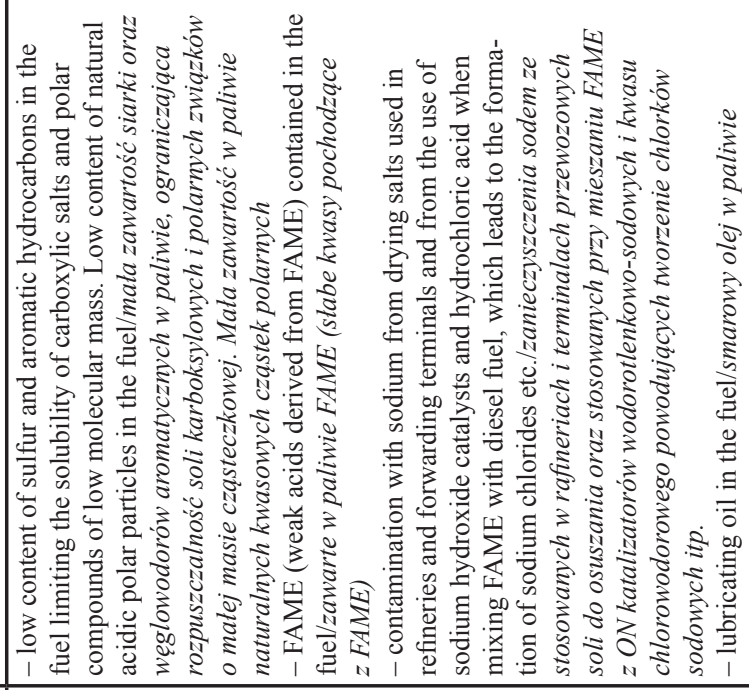 & 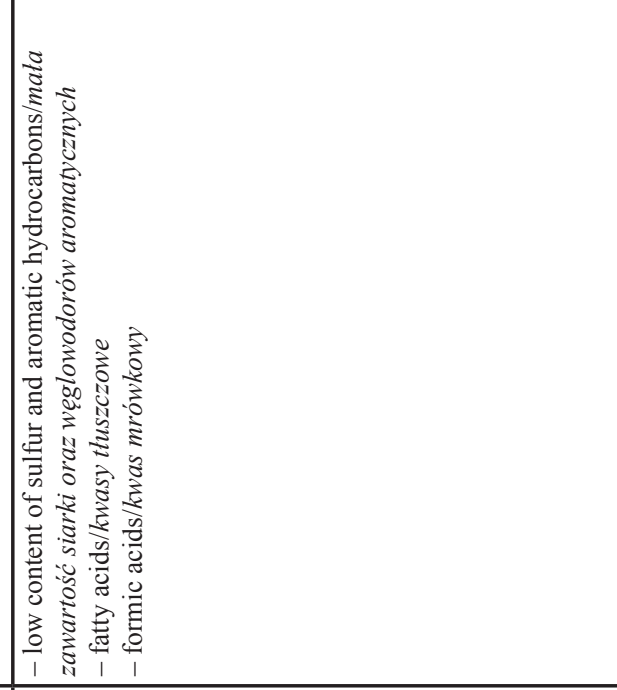 \\
\hline 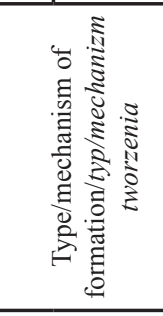 & 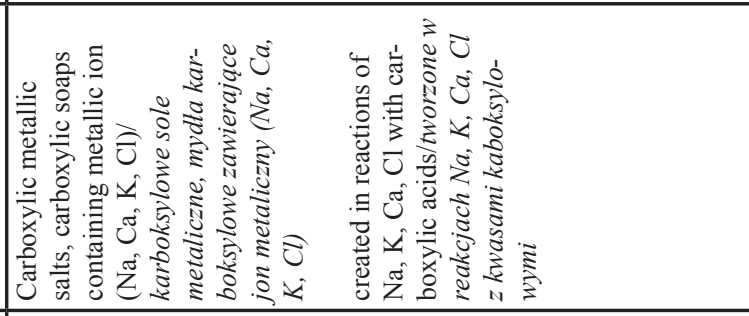 & 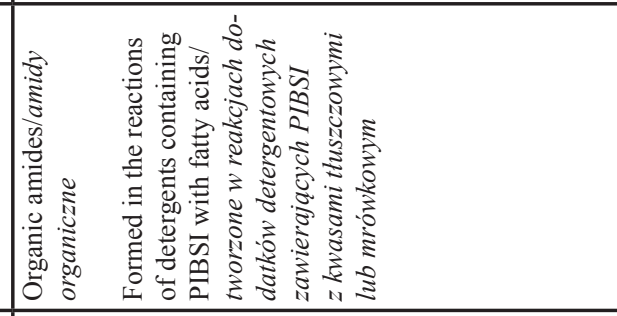 \\
\hline 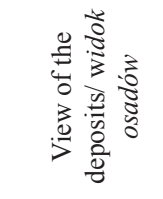 & & \\
\hline
\end{tabular}




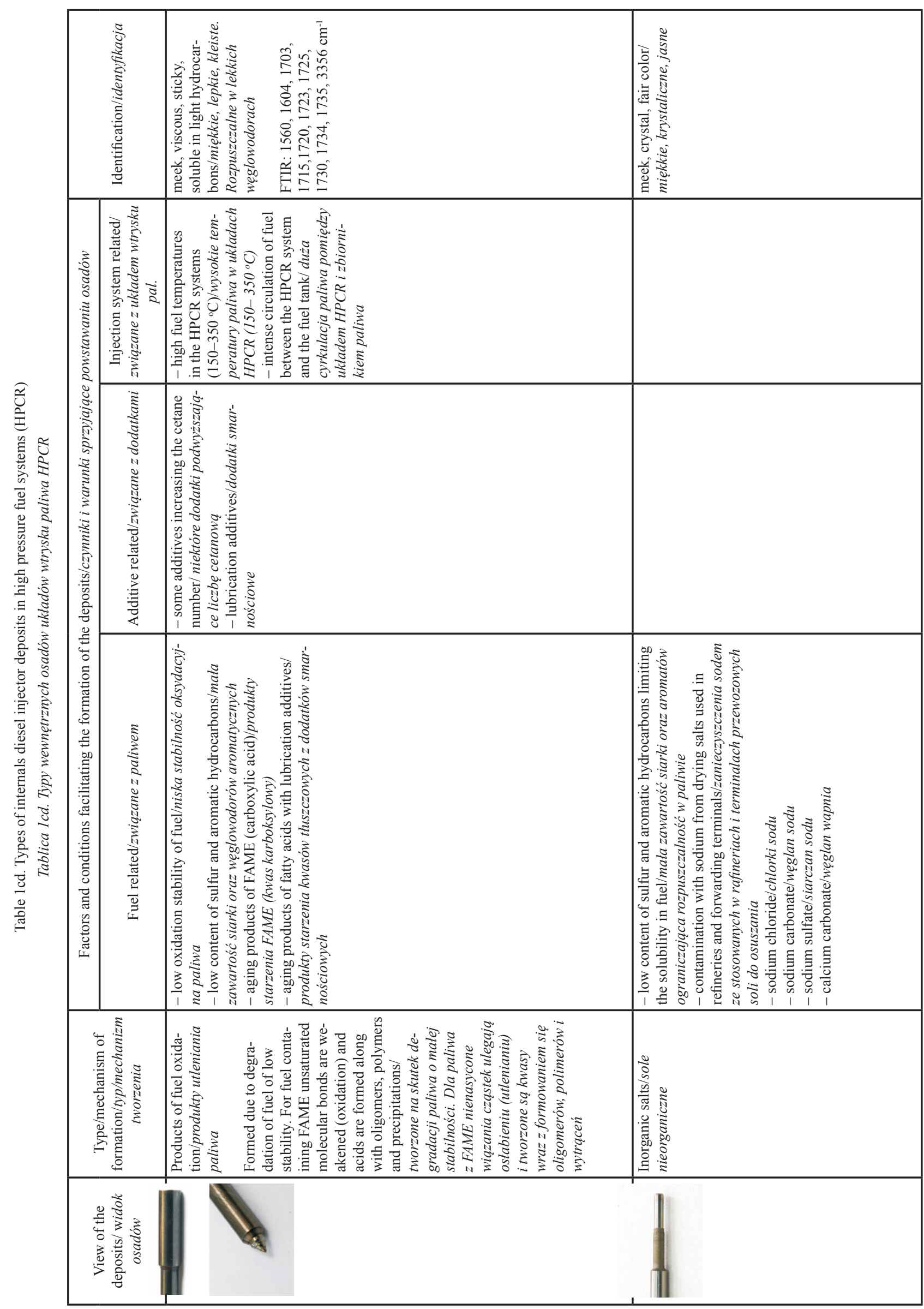


aged components or components of low stability. Hence, in the situation of significant oxidation of FAME during fuel storage, unsaturated bonds in the molecule degrade, leading to increased level of acids, polymers and precipitations. Such a mechanism of deposit formation occurs not only in the areas of high fuel temperature and pressure. Carboxylic acids, forming due to aging of FAME, lead to a corrosion of the elements containing iron and formation of carboxylic ferric salts, which leads to the formation of IDID.

To sum up, the formation of IDID is influenced by disadvantageous interactions of factors related to the engine maintenance, type and design of the injectors as well as the content of metallic contaminants, weak acids, detergents, lubrication additives and corrosion inhibitors in the fuel.

\section{Types of IDID in high pressure fuel systems}

Thus far, the investigations carried out on IDID (within the CRC Diesel Performance Group - Deposit Panel Bench/ Rig/ Investigation sub panel and, in Europe, by CEN TC19/ WG24 Injector Deposit Task Force, let alone all other scientific centers) led to distinguishing of their several types, out of which only two (carboxylic metallic salts and organic amides) are mentioned by all. The outstanding IDID types and the number of distinguished types are not uniform and differ in publications. We may only confirm that in most recent publications, a greater number of IDID types is distinguished, hence the authors attempt to systematize the already recognized types of IDID, the mechanisms of their formation as well as factors facilitating their formation based on known research results [1-3, 5, 7-11] - table 1 .

\section{The influence of IDID on the HPCR system functionality}

Due to very little play $(1 \mu \mathrm{m})$ between the working elements of the injectors, a formation of even very thin deposits $(0.5 \mu \mathrm{m})$, particularly on the mating surfaces between which pressurized fuel forces its way results in significant distortions in the injector operation. One should be mindful that the trends to further increase the fuel injection pressures will force a reduction in the said play between the mating injector pairs. Strong adhesion of the deposits to the working surfaces of the injectors results in quantitative and qualitative distortions in the fuel feed parameters (injection) in time. This results from significant differences between the actual onset of injection and the onset determined based on the injector control signals. The result is an inadmissible deregulation of part fuel doses in multiple injection, which results in temporal distortions in the start and end of individual parts of a multiple injection $[1,5,10]$. As a consequence the amount of injected fuel reduces when the start of injection is delayed or it increases if the injection ends later- Fig. 4.

If the injector needle and/or the moving parts of the injector valve metering the fuel dose 'hang', get stuck in the open position or close with delay due to increased resistance of the mating pairs caused by the deposits, an excess amount of fuel will be supplied to the combustion chamber. This will result in an increased smoke level and exhaust emissions (CO, $\mathrm{HC})$. This again, may lead to a malfunction of the aftertreatment rozpadają się, tworząc niestabilne cząstki polarne, które następnie wytrącają się na powierzchniach wewnętrznych elementów wtryskiwaczy formując IDID [5].

Amidy organiczne to osady polimerowe typu IDID tworzone w reakcjach dodatków detergentowych zawierających poliizobutylenowy imid kwasu bursztynowego (PIBSI) z kwasami tłuszczowymi lub mrówkowymi. Osady tego typu występują też często w powiązaniu z karboksylowymi solami sodowymi [1-3, 5-9]. W szczególności łańcuchy cząsteczek o mniejszej masie cząsteczkowej są mniej rozpuszczalne w paliwie i potencjalnie bardziej reaktywne, łatwo tworząc osady w obszarach wysokiej temperatury i ciśnienia. Osady polimerowe mogą także powstawać w wyniku niskiej stabilności paliwa, zwłaszcza gdy zawiera ono komponenty o małej stabilności lub już zestarzone. Dlatego też w sytuacji znacznego utlenienia FAME podczas przechowywania paliwa, nienasycone wiązania w cząsteczce degradują się, powodując wzrost zawartości kwasów wraz z formowaniem się polimerów i wytrąceń. Taki mechanizm tworzenia osadów występuje nie tylko w obszarach podwyższonego ciśnienia i temperatury paliwa. Kwasy karboksylowe powstające na skutek procesów starzenia FAME powodują korozję elementów zawierających żelazo i tworzenie karboksylowych soli żelazowych powodujących powstawanie IDID.

Podsumowując, na powstawanie IDID mają wpływ niekorzystne interakcje czynników związanych ze sposobem eksploatacji silnika, typem i budową wtryskiwaczy, a także zawartością metalicznych zanieczyszczeń, oraz słabych kwasów, dodatków detergentowych, smarnościowych i inhibitorów korozji w paliwie.

\section{Typy wewnętrznych osadów układów wysokociśnieniowego wtrysku paliwa}

Dotychczas przeprowadzone w ramach CRC Diesel Performance Group - Deposit Panel Bench/Rig/ Investigation sub panel, oraz w Europie przez CEN TC19/WG24 Injector Deposit Task Force, a także przez różne ośrodki naukowe badania IDID pozwoliły wyróżnić kilka ich typów, spośród których jedynie dwa, tzn. karboksylowe sole metaliczne oraz amidy organiczne, są wymieniane przez wszystkich. Pozostałe typy osadów IDID jak również liczba wyróżnianych typów nie są jednoznaczne i różnią się w dostępnych publikacjach. Można jedynie stwierdzić, że w nowszych publikacjach rozróżnia się większą liczbę typów IDID niż w starszych, dlatego poniżej podjęto próbę usystematyzowania dotychczas rozpoznanych typów osadów IDID oraz mechanizmów ich powstawania, a także czynników sprzyjających ich tworzeniu, opierając się na znanych wynikach badań $[1-3,5,7-11]$ - tabl. 1 .

\section{Wpływ osadów typu IDID na funkcjonowanie układów HPCR}

Ze względu na bardzo małe luzy (rzędu $1 \mu \mathrm{m}$ ) występujące pomiędzy głównymi elementami roboczymi wtryskiwaczy, wytworzenie się nawet bardzo cienkich warstw osadów (rzędu 0,5 $\mu \mathrm{m}$ ), zwłaszcza na powierzchniach ślizgowo współpracujących ze sobą elementów, pomiędzy którymi usiłuje przeciskać się paliwo poddane działaniu 


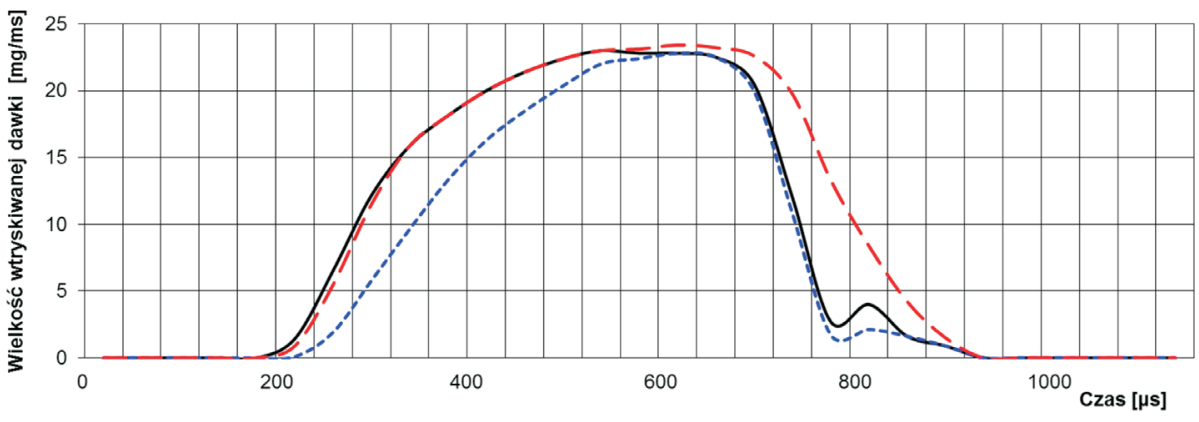

—Prawidłowy wtrysk paliwe

---- Wtrysk z opoźnionym początkiem

Fig. 4. Changes in the amount of the injected fuel dose resulting from IDID formation on the injector internal working surfaces

Rys. 4. Zmiany wielkości dawki wtryskiwanego paliwa spowodowane osadami typu IDID wytworzonymi na powierzchniach wewnętrznych elementów roboczych wtryskiwacza paliwa

systems and the turbocharger. If any of the mentioned injector actuators responsible for fuel dosage 'hangs' in the closed position or opens with delay, it will reduce the fuel dose supplied to the combustion chamber and, as a consequence, the engine power will be reduced or the engine will stop. The described processes occur irregularly and with varied intensity in individual engine cylinders, significantly disturbing the engine operation or even rendering it inoperative. The most frequently occurring external symptoms of deposit formation inside HPCR injectors are:

- reduced engine performance

- unstable engine operation at idle

- irregular engine operation

- diesel engine works harsh

- difficult engine starting

- increased fuel consumption

- increased exhaust emissions

\section{IDID proactive measures}

IDID poses a serious threat of global reach in terms of proper operation of HPCR injection systems. If this problem is not resolved, then, given the future trends in the development of injection systems, the risk of deposit related malfunctions will grow.

The manufacturers of injection systems try to prevent these adverse phenomena by introducing design changes, particularly of the injectors as subcomponents exposed to deposit formation. For example, DELPHI has modified the hydraulic fuel flow control valve of the injector - Fig. 2 . The changes consists in the application of a sleeve insert with a circumferential central external part machined - Fig. 5. The task of this sleeve is to reduce the leakage alongside the plunger and at the same time it is a guide in which the plunger operates. It is achieved as a result of compensating the pressure acting on the sleeve by draining the pressurized fuel to the circumferential crevice made around the external surface of the sleeve. The pressure reduces the sleeve internal diameter (small sleeve deformation), thus reducing the leakage while the fuel pressure rises and also limits the fuel
- -Wtrysk z opoźñionym zakoniczeniem

wysokiego ciśnienia, powoduje znaczne zaburzenia w działaniu wtryskiwacza. Przy tym należy pamiętać, że tendencje do dalszego zwiększania ciśnienia wtryskiwania paliwa będą wymuszały zmniejszanie przedmiotowych luzów pomiędzy poruszającymi się częściami wtryskiwaczy. Silne przyleganie, na skutek adhezji, osadów do powierzchni roboczych elementów wtryskiwaczy powoduje zaburzenia zarówno w ilościowym, jak i jakościowym podawaniu (wtryskiwaniu) paliwa do komór spalania w czasie. Wynika to $\mathrm{z}$ powstawania znacznych różnic pomiędzy rzeczywistym początkiem wtrysku paliwa a początkiem określonym na podstawie sygnałów sterujących pracą wtryskiwacza. Skutkiem tego jest niedopuszczalne rozstrojenie częściowych dawek paliwa wtrysku wielokrotnego. Występują czasowe zaburzenia w początku i zakończeniu wtrysku podzielonych na części dawek paliwa $[1,5,10]$. W konsekwencji ilość wtryskiwanego paliwa zmniejsza się, gdy początek wtrysku jest opóźniony lub zwiększa się, gdy wtrysk jest zakończony z opóźnieniem - rys. 4.

Jeśli iglica rozpylacza dozującego paliwo i/lub ruchome elementy zaworka odmierzającego dawkę paliwa „zawieszą się" lub skleją się w pozycji otwartej lub zamkną z opóźnieniem na skutek zwiększonych oporów ruchu spowodowanych osadami utworzonymi na współpracujących powierzchniach, wówczas nadmierna ilość paliwa zostanie doprowadzona do komory spalania silnika. Spowoduje to wzrost dymienia i emisji innych szkodliwych składników spalin (CO, HC). To z kolei może prowadzić do uszkodzenia układu oczyszczania spalin i turbosprężarki. Gdy któryś z wyżej wymienionych elementów wykonawczych wtryskiwacza odpowiadających za dawkowanie paliwa ,zawiesi się” w pozycji zamkniętej lub otworzy z opóźnieniem, spowoduje to zmniejszenie dawki paliwa doprowadzonego do komory spalania silnika i w konsekwencji zmniejszenie jego mocy lub nawet zatrzymanie. Oczywiście opisane procesy występują nieregularnie i z różnym nasileniem w poszczególnych cylindrach silnika, znacznie zaburzając lub nawet uniemożliwiając jego funkcjonowanie. Najczęściej występującymi zewnętrznym objawami powstania osadów we wtryskiwaczach układów wtrysku paliwa typu HPCR są:

- zmniejszenie osiągów silnika

- niestabilna praca silnika na biegu jałowym

- nierównomierna praca silnika

- twarda praca silnika ZS

- trudności z uruchomieniem silnika

- wzrost zużycia paliwa

- wzrost emisji składników szkodliwych w gazach spalinowych silnika 


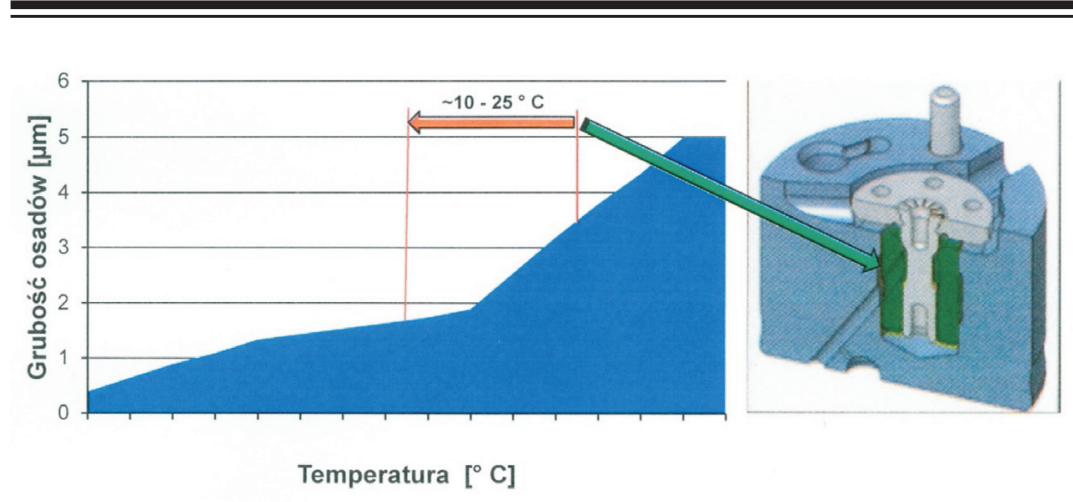

Fig. 5. The influence of design changes of a hydraulic fuel flow control valve inside the injector on the thickness of the IDID deposits [15]

Rys. 5. Wpływ zmian konstrukcyjnych hydraulicznego zaworu sterujacego przepływem paliwa we wtryskiwaczu na grubość tworzonych IDID [15]

leakage resulting from the ongoing wear and tear process of the sleeve and the plunger. A reduction of the fuel leakage between the plunger and the sleeve not only improves the system operation but limits the fuel temperature forcing its way through the sleeve and the plunger (by approx. 10-25 ${ }^{\circ} \mathrm{C}$ ) - Fig. 5, which has a positive effect on the IDID formation reducing trend in the said area [15].

Among other modifications to the design of the injector that have also been introduced are elimination of the circumferential grooves around the plunger of the hydraulic valve (this facilitated accumulation of deposits Fig. 2), reduction of the diameter of the guiding part of the injector needle, increase of the force of the spring and the electromagnet controlling the opening and closing of the hydraulic valve in order to reduce the sensitivity of the valve to increased friction forces (resulting from the deposits forming on the surfaces of mating pairs) and reducing the cavitation effect in the area of the hydraulic valve channels (accelerated fuel degradation) [16].

From the point of view of the fuel manufacturers, fuels should not contain any metallic contaminants being the most important causes of IDID formation. Particularly hazardous is the content of sodium, sodium chloride and sodium hydroxide. Corrosion inhibitors also increase the risk of deposit formation along with low fuel stability. Greatest hopes, however, are pinned to the development of a new group of detergent, optimized in terms of chemical composition and dosage to efficiently prevent IDID precipitation. Currently, widely applied detergents preventing external coke deposits on the injectors are based on PIBSI (Polyisobutylene Succinimide) and in combination with the previously described factors may facilitate the formation of IDID. It is, thus, necessary to develop a universal effective additive of cleaning/dispersive properties fully compatible with all additives and components of modern diesel fuels that would limit the formation of both IDID and external coke deposits formed in the outlet channels of the injector and around the injector holes. Currently, several globally recognized manufacturers of additives are attempting to develop a formula that will serve this purpose.

\section{Przeciwdzialanie powstawaniu IDID}

Już obecnie IDID stanowią duże zagrożenie, o zasięgu globalnym, dla poprawnego funkcjonowania układów wtrysku paliwa typu HPCR. Jeżeli problem ten nie będzie rozwiązany, to biorąc pod uwage przyszłe kierunki rozwoju układów wtrysku paliwa, niebezpieczeństwo powstawania ich awarii związanych z występowaniem przedmiotowych osadów będzie rosło.

Producenci układów wtrysku paliwa starają się przeciwdziałać tym niekorzystnym zjawiskom przez wprowadzanie zmian konstrukcyjnych, zwłaszcza w budowie wtryskiwaczy, jako podzespołów najbardziej narażonych na występowanie osadów. Przykładowo, firma DELPHI wprowadziła modyfikację budowy hydraulicznego zaworu sterującego przepływem paliwa we wtryskiwaczu - rys. 2. Zmiana polega na zastosowaniu w korpusie przedmiotowego zaworu wkładki w postaci tulejki z obwodowym podtoczeniem jej środkowej, zewnętrznej powierzchni - rys. 5. Zadaniem tulejki jest ograniczenie przecieków paliwa wzdłuż nurnika zaworka, a zarazem stanowi ona prowadnicę, w której się on porusza. Jest to osiągane na skutek zrównoważenie ciśnienia oddziałującego na tulejkę przez doprowadzenie paliwa pod wysokim ciśnieniem do obwodowej szczeliny wykonanej wokół zewnętrznej powierzchni tulejki. Ciśnienie to przez niewielkie odkształcenia tulejki wpływa na zmniejszenie jej wewnętrznej średnicy, zmniejszając nieszczelność w czasie zwiększania ciśnienia paliwa podczas pracy zaworka, a zarazem ograniczając przecieki paliwa wynikające z postępujących procesów zużycia ślizgowo współpracującego nurnika zaworka z tulejką podczas eksploatacji. Zmniejszenie przecieków paliwa pomiędzy nurnikiem i tulejką nie tylko poprawia sprawność działania układu, ale także ogranicza temperaturę nagrzewania się paliwa przeciskającego się pomiędzy tuleją a poruszającym się w niej nurnikiem (o około $10-25^{\circ} \mathrm{C}$ ) - rys. 5, co ma korzystny wpływ na zmniejszenie tendencji do tworzenia IDID w przedmiotowym obszarze [15].

Inne zmiany, jakie równocześnie wprowadzono w konstrukcji wtryskiwacza to zlikwidowanie obwodowych rowków wokół nurnika zaworka hydraulicznego, ułatwiających kumulowanie się osadów (rys. 2), zmniejszenie średnicy prowadzącej części iglicy wtryskiwacza, zwiększenie siły działania sprężyny i elektromagnesu sterującego otwieraniem i zamykaniem zaworka hydraulicznego w celu ograniczenia czułości zaworka na zwiększone opory tarcia, wynikające z tworzenia osadów na powierzchniach elementów współpracujących ślizgowo, a także ograniczenie zjawisk kawitacji w obrębie kanalików zaworka hydraulicznego przyspieszających procesy degradacji paliwa [16].

Z punktu widzenia producentów paliw, wytwarzane paliwa nie powinny zawierać nawet śladowych ilości zanieczyszczeń metalicznych, które stanowią jedne z najistotniejszych 


\section{Conclusions}

In September 2011 within the CEC/TC 19/WG 24 an Ad-Hoc Injector Sticking Task Force was created whose mission was to comprehensively explore the global problem of formation and consequences of harmful internal deposits inside the HPCR injection systems. At the end of 2012 a decision was made to create a task force (within the Coordinating European Council for the Development of Performance Tests for Fuels, Lubricants and Fluid) of CEC TDG-F-110 IDID to develop a new test procedure for the assessment of the influence of IDID on the functioning of fuel injection systems in the aspect of limited engine performance.

Tests on IDID, conducted thus far, allowed an assumption of several mechanisms of deposit formation. Yet, each of these mechanisms requires further investigations for validation purposes. This results from a high level of complexity of the factors and conditions that may influence the formation of deposits and their increment. It has already been confirmed that not only the fuel composition including its additives (detergents, lubrication anti-corrosion) is impactful but various fuel contaminants (even in the amounts below $1 \mathrm{ppm}$ ), quantity and quality of FAME contained in the fuel, engine operating conditions as well as a variety of adverse interactions that may take place among these factors. Besides, the chemical structure, i.e. the types of the said deposits may differ. The boundary conditions for which IDID may form are not known either. All this makes further multi directional exploratory research on deposit formation mechanisms, structure, morphology and composition indispensable. Only these investigations will constitute a basis for the development and optimization of efficient detergent - dispersive additives as the most efficient tool to prevent the formation of IDID.

There are many premises that the current trend in the engine development in terms of downsizing may increase the number of factors facilitating the formation of IDID and their intensification, particularly since, in further development of precisely operating injection systems, engineers see a great potential in the reduction of exhaust emissions, including $\mathrm{CO}_{2}$. The conditions that have to be fulfilled by the fuel injection systems to meet the expectations will not only be their further development in terms of precise fuel dose control and atomization in time but maintaining these parameters throughout the entire vehicle life cycle, on which the formation of IDID has a strong influence.

\section{Abbreviations/Skróty i oznaczenia}

CEC CO-ordinating european council for development of performance tests for transportation fuels, lubricants and other fluids/Europejska Rada Wspótpracy w Zakresie Opracowywania Testów Eksploatacyjnych dotyczacych Badania Paliw, Środków Smarowych i Innych Ptynów dla Transportu Samochodowego

CEN The European Committee for Standardization/Europejski Komitet do Spraw Normalizacji

DDSA dodecenyl succinica acid/dodecenylowy kwas bursztynowy

FAME Fatty Acid Ethyl Esters/estry metylowe kwasów tłuszczowych czynników powodujących powstawanie IDID. Szczególnie niebezpieczna jest zawartość $\mathrm{w}$ paliwie sodu w postaci azotynu sodu, chlorku sodu lub wodorotlenku sodu. Duże zagrożenie stwarzają też inhibitory korozji, a także niska stabilność paliwa. Jednak największe nadzieje pokładane są w opracowaniu nowej grupy dodatków detergentowych, zoptymalizowanych pod względem składu chemicznego i wielkości dozowania dla skutecznego przeciwdziałania wytrącaniu się IDID. Obecnie szeroko stosowane dodatki detergentowe do przeciwdziałania powstawaniu zewnętrznych osadów koksowych wtryskiwaczy paliwa oparte są na PIBSI (Polyisobutylene Succinimide) i w połączeniu z wcześniej opisanymi czynnikami mogą sprzyjać powstawaniu IDID. Zatem niezbędne jest opracowanie uniwersalnego, efektywnego dodatku o właściwościach detergentowo-dyspergujących w pełni kompatybilnego z wszystkimi dodatkami i komponentami nowoczesnych olejów napędowych, który będzie ograniczał powstawanie zarówno IDID, jak i zewnętrznych, koksowych osadów tworzących się w kanalikach wylotowych i wokół otworków dozujących paliwo wtryskiwaczy. Obecnie kilku renomowanych producentów dodatków na świecie podejmuje próby wytworzenia dodatku detergentowego pełniącego taką funkcję.

\section{Podsumowanie}

We wrześniu 2011 r. w ramach CEC/TC 19/WG 24 została utworzona tzw. Ad-Hoc Injector Sticking Task Force, mająca zająć się kompleksowym rozpoznaniem globalnego problemu powstawania i skutków działania szkodliwych, wewnętrznych osadów tworzonych w układach wtrysku paliwa typu HPCR. Pod koniec 2012 r. zdecydowano o założeniu w ramach CEC (Coordinating European Council for the Development of Performance Tests for Fuels, Lubricants and Fluid) nowej grupy roboczej CEC TDG-F-110 IDID w celu opracowania nowej procedury badawczej do oceny wpływu IDID na funkcjonowanie układów wtrysku paliwa w powiązaniu z ograniczaniem osiągów silników.

Dotychczas przeprowadzone badania IDID pozwoliły założyć kilka mechanizmów tworzenia takich osadów, jednak każdy z tych mechanizmów wymaga prowadzenia dalszych badań w celu ich zweryfikowania i/lub ostatecznego potwierdzenia. Wynika to z dużej złożoności czynników i warunków mogących mieć wpływ na inicjowanie powstawania, a następnie na tworzenie i przyrost przedmiotowych osadów. Ustalono już, że mają na to wpływ nie tylko: określony skład paliwa i uszlachetniających go dodatków (np. detergentowych, smarnościowych, przeciwkorozyjnych), ale także różne zanieczyszczenia paliwa (nawet w ilościach poniżej 1 ppm), ilość i jakość zawartego w paliwie FAME, warunki pracy silnika, a także wiele niekorzystnych interakcji mogących występować pomiędzy tymi czynnikami. Ponadto struktura chemiczna, a zatem i typy przedmiotowych osadów, mogą być różne. Dodatkowo nie są znane graniczne warunki, w których IDID mogą powstawać. Wszystko to sprawia, że niezbędne są dalsze, wielokierunkowe badania poznawcze w zakresie mechanizmów tworzenia, struktury, morfologii i składu przedmiotowych osadów. Dopiero te badania będą stanowiły podstawę do opracowania, a następnie 
FTIR Fourier Transform Infrared Spectroscopy/spektroskopia $w$ podczerwieni z transformacja Fouriera

HDSA hexadecenyl succinic acid/heksadecylowy kwas bursztynowy

DPF Diesel Particulate Filter/filtr czastek statych

HPCR High Pressure Common Rail/wysokociśnieniowy uktad wtryskowy Common Rail

HSDI High Speed Direct Injection/szybki wtrysk bezpośredni

IDID Internal Diesel Injector Deposits/osady wewnętrzne we wtryskiwaczach silników z zaptonem samoczynnym

PIBSI Polyisobutylene Succinimide/poliizobutylenowy imid kwasu bursztynowego optymalizacji skutecznych dodatków detergentowo-dyspergujących jako najskuteczniejszego sposobu zapobiegającego powstawaniu IDID.

Wiele wskazuje też na to, że obowiązujący obecnie kierunek rozwoju silników w zakresie tzw. downsizingu może prowadzić do zwiększenia i pogłębienia czynników sprzyjających powstawaniu IDID. Zwłaszcza, że w dalszym rozwoju precyzyjnie działających układów wtrysku paliwa upatruje się dużego potencjału w zakresie ograniczenia emisji szkodliwych składników spalin z silników, w tym także emisji $\mathrm{CO}_{2}$. Jednak warunkiem spełnienia przez układy wtrysku paliwa pokładanych w nich oczekiwań będzie nie tylko dalszy rozwój ich konstrukcji pod kątem uzyskiwania wymaganej precyzji kształtowania i jakości rozpylania wtryskiwanej dawki paliwa w czasie, ale także zagwarantowanie utrzymywania ich parametrów pracy podczas długotrwałej eksploatacji pojazdu, na co decydujący wpływ będzie miało skuteczne przeciwdziałanie tworzeniu się IDID.

\section{Bibliography/Literatura}

[1] Stępień Z. The reasons and adverse effect of internal diesel injector deposits formation - Przyczyny powstawania i szkodliwy wpływ wewnętrznych osadów we wtryskiwaczach silników o zapłonie samoczynnym - Combustion Engines (Silniki Spalinowe), No 1/2014 (156) ISSN 0138-0346, s. 20-29.

[2] Stępień Z. Przyczyny i skutki tworzenia wewnętrznych osadów we wtryskiwaczach silnikowych układów wysokociśnieniowego wtrysku paliwa. Nafta-Gaz, marzec 2013, nr 3/2013 s.256-262. Wydawnictwo Instytutu Nafty i Gazu, ISSN 08678871.

[3] Żak G., Ziemiański L., Stępień Z., Wojtasik M. Problemy związane z tworzeniem się osadów na elementach układów wtryskowych nowoczesnych silników Diesla - przyczyny, metody badań, przeciwdziałanie. Nafta-Gaz, wrzesień 2013, nr 9/2013 s.702-708. Wydawnictwo Instytutu Nafty i Gazu, ISSN 0867-8871.

[4] Internal Diesel Injector Deposits, CRC Project No. DP-04-13a, october 2013, Coordinating Research Council, INC.

[5] Trobaugh C., Burbrink C., Zha Y., Whitacre S., Corsi C., Blizard N. Internal Diesel njector Deposits: Theory and Investigations into Organic and Inorganic Based Deposits; SAE Technical Paper 2013-01-2670.

[6] Caprotti R., Bhatti N., Balfour G. Deposit Control in Modern Diesel Fuel Injection Systems; SAE Technical Paper 201001-2250.

[7] Internal Diesel Injector Deposits, Coordinating Research Council, INC., CRC Project No. DP-04-13a, CRC Report No. 665 - October 2013.

[8] Ullmann J., Gedulding M., Stutzenberger H., Caprotti R., Balfour G. Effects of Fuel Impuerities and Additive Interactions on the Formation of Internal Diesel Injector Deposits; TAE Fuels 8th Annual Colloquium, January 2011.

[9] Lacey P., Gail S., Marc J., Benoist G., Downes P., Daveau P. Fuel Quality and Diesel Injector Deposits; SAE Technical Paper 2012-01-1693.

[10] Tanaka A., Yamada K., Omori T., Bunne S., Hosokawa K. Inner Diesel Injector Deposit Formation Mechanism; SAE Technical Paper 2013-01-2661.
[11] Ullmann J., Gedulding M., Stutzenberger H., Caprotti R., Balfour G. Investigation into the Formation and Prevention of Internal Diesel Injector Deposits; SAE Technical Paper 2008-01-0926.

[12] Barker J., Richards P., Goodwin M., Wooler J.; Influence of High Injection Pressure on Diesel Fuel Stability: A Study of Resultant Deposits; SAE Technical Paper 2009-01-1877.

[13] Quigeley R., Barbour R., Fahey E., Arters D., Wetzel W., Ray J. A Study of The Internal Diesel Injector Deposit Phenomenon; TAE Fuels 7th Annual Colloquium, January 2009.

[14] Caprotti R., Breakspear A., Klaua T., Weiland P., Graupner O., Bittner M. RME Behaviour in Current and Future Diesel Fuel FIE's; SAE Technical Paper 2007-01-3982.

[15] Judge R., Beduneau J-L., Boncompte X., Cardon Ch., Dale M., Ralph M., Schiffgens H. The Next Generation of Delphi Common Rail Systems for Light and Medium Duty Commercial Vehicles; 23rd Aachen Colloquium Automobile and Engine Technology 2014, October 2014.

[16] Beduneau J-L., Cardon C., Meissonnier G., Uberti Bona M., Voigt P., Bercher P., Schiffgens H-J. Delphi New Diesel Common Rail System Family; 35 Internationales Wiener Motorensymposium 2014, May 2014.

Zbigniew Stępień, DEng. - Assistant Professor, Head of Laboratory of Engine and Tribological Research, Deputy Head of the Chair of Operational Properties Assessment of Oil and Gas Institute at National Research Institute in Krakow.

Dr inż. Zbigniew Stępień - adiunkt, kierownik Laboratorium Badań Silnikowych i Trybologicznych, z-ca kierownika Zakładu Oceny Właściwości Eksploatacyjnych w Instytucie Nafty i Gazu w Państwowym Instytucie Badawczym w Krakowie. e-mail: stepien@inig.pl 